\title{
HOST COMMUNITY'S PERCEPTION TOWARDS SOCIO-CULTURAL IMPACTS OF TOURISM: AN ANTHROPOLOGICAL STUDY OF HOST DESTINATIONS OF KASHMIR
}

\author{
Mudasir Ahmad Mir*
}

\begin{abstract}
The study endeavors to know the host community's perception regarding the socio-cultural impacts of tourism in the tourist destination of Gulmarg. The present study adopted a quantitative approach and distributed the questionnaire among the respondents of the study. The investigation is based on the findings of a survey of 147 residents of tourist destination. For descriptive statistics and factor analysis technique SPSS (Statistical Package for Social Sciences) software was used. The unidimensionality (Confirmatory Factor Analysis CFA) of the identified factors was tested through AMOS. The findings of the study revealed that host community perceive positive socio-cultural impacts of tourism i.e. the host residents perceive that the tourism development is creating employment opportunities, improving local peoples' incomes, and stimulating the local economy. Residents in tourist destination also agreed that tourism has improved security in their local communities and has preserved and conserved the local culture and traditions of the area. Furthermore, the findings of the survey revealed that host communities do not perceive any socio-cultural negative impact of the tourism development in the area. Therefore, the investigation will assist tourism planners and local government in the planning and implementation of tourism development strategies for the area aiming at consolidating local residents' support for tourism.
\end{abstract}

Key words: Socio-cultural impacts; Host community; Tourism.

\section{PERCEPÇÃO DA COMUNIDADE ANFITRIÃ EM RELAÇÃOAOS IMPACTOS SOCIOCULTURAIS DO TURISMO:UM ESTUDO ANTROPOLÓGICO DOS DESTINOS ANFITRIÕES DA CAXEMIRA}

Resumo: O estudo procura conhecer a percepção das comunidades anfitriãs a respeito dos impactos socioculturais do turismo no destino turístico de Gulmarg. O presente estudo adotou uma abordagem quantitativa e distribuiu o questionário entre os respondentes do estudo. A investigação se baseia nos resultados de uma pesquisa com 147 residentes do destino turístico. Para estatística descritiva e técnica de análise fatorial foi utilizado o software SPSS (Statistical Package for Social Sciences). A unidimensionalidade (Confirmatory Factor Analysis CFA) dos fatores identificados foi testada através do AMOS. Os resultados do estudo revelaram que a comunidade anfitriã percebe impactos socioculturais positivos do turismo, ou seja, os residentes anfitriões percebem que o desenvolvimento do turismo está criando oportunidades de emprego, melhorando a renda das pessoas locais e estimulando a economia local. Os residentes no destino turístico também concordaram que o turismo melhorou a segurança em suas comunidades locais e preservou e conservou a cultura e tradições locais da área. Além disso, os resultados da pesquisa revelaram que as comunidades anfitriãs não percebem nenhum impacto sócio-cultural negativo do desenvolvimento do turismo na área. Portanto, a investigação ajudará os planejadores de turismo e o governo local no planejamento e implementação de estratégias de desenvolvimento turístico para a área, visando consolidar o apoio dos residentes locais ao turismo.

Palavras-chave: Impactos socioculturais; Comunidade anfitriã; Turismo.

\section{LAPERCEPCIÓN DELACOMUNIDAD DEACOGIDAHACAA LOS IMPACTOS SOCIOCULTURALES DELTURISMO:UNESTUDIO ANIROPOLÓGICO DE LOSDESTINOSDEACOGIDA DE CACHEMIRA}

Resumen: El estudio trata de conocer la percepción de las comunidades de acogida sobre los impactos socioculturales del turismo en el destino turístico de Gulmarg. El presente estudio adoptó un enfoque cuantitativo y distribuyó el cuestionario entre los encuestados del estudio. La investigación se basa en los resultados de una encuesta realizada a 147 residentes del destino turístico. Para la estadística descriptiva y la técnica de análisis factorial se utilizó el software SPSS (Statistical Package for Social Sciences). La unidimensionalidad (análisis factorial confirmatorio CFA) de los factores identificados se comprobó mediante AMOS. Los resultados del estudio revelaron que la comunidad anfitriona percibe impactos socioculturales positivos del turismo, es decir, los residentes anfitriones perciben que el desarrollo turístico está creando oportunidades de empleo, mejorando los ingresos de la población local y estimulando la economía local. Los residentes de los destinos turísticos también coinciden en que el turismo ha mejorado la seguridad en sus comunidades locales $y$ ha preservado $y$ conservado la cultura y las tradiciones locales de la zona. Además, los resultados de la encuesta revelaron que las comunidades anfitrionas no perciben ningún impacto sociocultural negativo del desarrollo turístico en la zona. Por lo tanto, la investigación ayudará a los planificadores turísticos y al gobierno local en la planificación y aplicación de estrategias de desarrollo turístico para el area con el objetivo de consolidar el apoyo de los residentes locales al turismo.

Palabras clave: Impactos socioculturales; Comunidad anfitriona; Turismo.

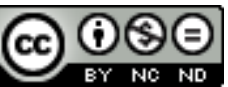

Licenciada por Creative Commons Atribuição Não Comercial / Sem Derivações/4.0/Internacional
* Ph.D. Pursuing in Tourism Management/Central University of Kashmir (2021). Masters in Anthropology/ Indira Gandhi National Open University (2020). Master in Tourism Management/Central University of Kashmir (2014). Bachelor in Business Administration/ University of Kashmir (2012). SRF Doctoral fellow at Central University of Kashmir. CV: https://orcid.org/0000-0002-3647-7551 [ mirmudasir357@gmail.com ] 


\section{INTRODUCTION}

Tourism is being considered as a desired growth instrument as well as lucrative substitute to the conventional principal as well as auxiliary industries in emergent nations (Opperman \& Chon, 1997). Numerous emerging nations are considering tourism as a vehicle for growth because it is among those lucrative industries which follow a laissez faire policy.

Emergent nations are seeking tourism as a remedy to poverty and overall growth because of tourisms fast and continuous growth with promising remunerative contribution (Binns \& Nel, 2002). In 2019, Travel \& Tourism's direct, indirect and induced impact accounted for US\$8.9 trillion contribution to the world's GDP (i.e. 10.3\% of global GDP); 330 million jobs, 1 in 10 jobs around the world; US\$1.7 trillion visitor exports (i.e. $6.8 \%$ of total exports, $28.3 \%$ of global services exports) and US\$948 billion capital investment (i.e. 4.3\% of total investment) (WTTC, 2020). 2019 was another year of strong growth for the global Travel \& Tourism sector reinforcing its role as a driver of economic growth and job creation.

WTTC's latest annual research, in conjunction with Oxford Economics shows the Travel \& Tourism sector experienced 3.5\% growth in 2019, outpacing the global economy growth of $2.5 \%$ for the ninth consecutive year. Over the past five years, one in four new jobs were created by the sector, making Travel \& Tourism the best partner for governments to generate employment (WTTC, 2020). Central as well as outback regions which harnessed the tourism hoards ended up in creation of infinite job opportunities. These destination sites also provide an interactive platform between guests and the hosts.

Tourism, as a significant form of human activity, can have major impacts. These impacts are very visible in the destination region, where tourists interact with the local environment, economy, culture and society. Hence, it is conventional to consider the impacts of tourism under the headings of socio-cultural, economic and environmental impacts. Tourism impacts are likely to change over time as a destination area develops (Butler, 1980).

According to Wall (1996), key factors contributing to the nature of the impacts are the type of tourism activities engaged in, the characteristics of the host community in the destination region and the nature of the interaction between the visitors and residents. Davison (1996) suggested a range of similar influences and also included the importance of time and location in relation to tourism impacts.

Host communities support is indispensible for the sustenance of tourism industry (Ryan, Chaozhi, \& Zeng, 2011). So, research over the social implications which aim at the evaluation of the degree of host involvement form a base for sound tourism planning as well as decision making (Tovar \& Lockwood, 2008).

After being aware about the potential benefits of tourism more attention has been given to it in terms of developmental planning and policy considerations (Ap, 1992; Ap \& Crompton, 1998; Lankford, 1994). Tourism activities at any geographical location has pros as well as cons. Surge in crime frequency (Fletcher, Fyall, Gilbert \& Wanhil, 2013), deterioration of established customs or beliefs (Cooper \& Hall, 2008), swarming public places in addition to gridlocks (George, 2015) are some of the cons of tourism activities at a place.

These impacts tend to affect local host communities and should be understood from this perspective. Since hosts are the primary stakeholders who are swayed by these pros and cons so while understanding its percieved influence this fact must be kept in mind. Host communities are regarded as one of the major stakeholders in tourism since they are most affected by tourism planning and development. Hence the prerequisite while sound decision making stresses upon the clear sightedness about the way hosts consider tourism as well as its implications (Eshliki \& Kaboudi, 2012).

Acha-Anyi (2016) are of the opinion that for addressing the problems regarding stakeholder management more efficient planning regarding tourism is must. Hosts form the part and parcel component for tourism growth as stated earlier even then the role played by them is never given due importance. Deery, Jago and Fredline (2012) are of the view that in nations where tourism is developed research regarding the tourisms social implications are given due importance and is continuously going on.

Out of the considerable research done on the subject regarding the issue most of the research has been done in advanced nations rather than emergent nations (Eshki \& Kaboudi, 2012; Sharpley, 2014; Manivannan, 2015; Alrwajfah, Almeida-García \& Cortés-Macías, 2019). Maximum research results were in contrast with the expected results (Dyer, Gursoy, Sharma, \& Carter, 2007) and the reason put forward by Tosun (2002) is that the contrast in the results may be 
because of the variations in the area under study as the socio-cultural implications vary greatly with the area under study because of the variation in the essence of the guest-host relatedness.

Therefore, researchers have found a great scope to carry out additional studies but in heterogeneous geographical location (Tosun, 2002). With this in mind, this paper assesses perception of host communities towards the socio-cultural impacts of tourism development in the host destinations of Kashmir.

This paper advances our understanding of the socio-cultural impacts of tourism in host destination. In nut shell present study will add the knowledge that is key to the successful development, management and marketing of existing and future tourism developments (Brunt \& Courtney, 1999; Lankford, 1994).

\section{REVIEW OF LITERATURE}

The literature on socio-cultural effects of tourism is quite extensive, but the majority of the contributions are concerned with specific in particular countries. For instances most of the contributions have made by authors like Dogan (1989), Dann and Cohen (1991), Smith and Brent (2001) and Reisinger and Turner (2003).

But there is need for many more multidisciplinary studies where sociologists can contribute the insights of their discipline to the study of particular aspects of the tourism phenomenon or the analysis of the tourism in specific countries and regions. Also McKercher (1993) argued that more research is needed regarding the impacts of tourism.

The Inter-organization committee (1994) suggested that the Social Impact Assessment (SIA) practitioner should focus on the more significant impacts, use appropriate measures and information, provide quantification where feasible and appropriate, and present the social impacts in a manner that can be understood by decision makers and community leaders. Thus, our investigation assesses the sociocultural impacts of tourism from the host communities' perspective.

\subsection{Social and Cultural Impacts}

Social and cultural implications associated with tourism may be studied by treating the two distinctly by taking them conjoint as: tourism impact studies, tourist - host interaction, tourist systems and tourists and their behaviour (Cooper, Fletcher, Fyall, Gilbert, \& Wanhill, 2008). Probing studies have delineated the socio- cultural influences of tourism under three headings viz; a) the host, b) the tourist and c) the tourist-host interrelationship. Present study pivots over the tourist-host interrelationships, so as to portray consequence of these relationships between tourist and local community (Wall \& Mathieson, 2006).

After Smith's (1977) influential contribution under the name "Hosts and guests - The anthropology of tourism" among the three categories of studying socio-cultural impressions by tourism, the tourist-host relationship holds prime importance". The international tourism has been debated topic for researchers so as to represent diverse nature of sociocultural traits of guests and hosts. These differences have a bearing on the magnitude of direct sociocultural impacts associated with tourism development (Inskeep, 1991). These socio-cultural traits comprise of: basic value and logic system, religious beliefs, traditions, customs, lifestyles, behaviour patterns, dress code, sense of time and attitudes towards strangers (Inskeep, 1991).

Tourism may be defined as non permanent motion undertaken by humans from their permanent settlement and actions done by them at such temporary places to fullfill wants and desires (Mathieson and Wall 1982:1). At the time of stay tourists communicate with the local people of that place which result in cultural exchange and resultant is quite visible over certain aspects like quality of life, value systems, labour division, family relationships, attitudes, behavioural patterns, ceremonies and creative expressions (Fox, 1977; Cohen, 1984; Pizam and Milman, 1984). This variation in behaviour of host is directly proportional to the difference in value system of guest and host that is more the differences in cultural and economic traits more visible are changes too (Mathieson and Wall, 1982). The variations in host community's standard of living are imparted by two elements: the tourist-host relationship and the advancement in tourism sector.

Tourist faces local community mostly at one of the following occasions: while purchase of commodities from locals, while coming across each other at some place and while talking to each other (De Kadt, 1979). The last category of interaction is not more frequent in comparison to the first and second as tourism lags in encouraging mutual understanding of nations and typical dogma persists (Nettekoven, 1979; Krippendorf, 1987; O'Grady, 1990).

The relation between tourist and host has certain attributes a) It is temporary, dissimilar and unstable 
constraint restricted by geographical and chronological parameters (UNESCO, 1976); (b) the tourist visits destination spot for a brief period, hence inadequate scope for building any sort of deep and serious relationship (Sutton, 1967); (c) the customary voluntary helpfulness becomes business pursuit (de Kadt 1979; Jafari 1989); (d) the tourists on vacations are attended by locals therefore representing different sentiments and conduct (Sutton, 1967); and (e) more wealthy the tourists more are the chances of exploitation (Nettekoven, 1979).

The major influences of tourists host interaction are the conformation effect while host's conduct is amended to copy tourists,(Duffield \& Long, 1981; Crandall, 1987; Pearce, 1989; Tsartas, 1992); the shift in linguistic adaptation at destination (White, 1974; Brougham and Butler, 1977; Jeffs and Travis 1989; Wallace, 1997); the hike of alcoholics, crime, prostitution and staking (Young, 1973; Graburn, 1983; O'Grady, 1990) and the transformation (revitalisation or commoditisation) of the material and nonmaterial forms of local culture (UNESCO, 1976; Mill, 1990; Evans, 1994).

Transformation in the quality of life, social structure and social organization of host community is caused by the advancement of the tourism sector in addition to the physical presence of tourists and their interaction with host community.

Rigorous and speedy tourism growth impacts but not more than organic and small-scale growth (De Kadt, 1979; Krippendorf, 1987; Pearce, 1989; Peck \& Lepie, 1989). The growth of tourism sector favours in employment succession in that place (Crandall, 1987; Pearce, 1989). Although maximum number of jobs generated by tourism are periodic, untrained and with low wages (Vaughan \& Long, 1982; Allcock, 1986), which alter local working module, developing an attitude of neglecting agricultural work (Verbole, 1995; Crick, 1996).

Besides these tourism alters size and demographic features of host population (Crandall, 1987; Jeffs \& Travis, 1989); change in community morphology (Duffield \& Long, 1981; Haukeland, 1984); hike in movement of females and youngsters (Mason, 1990; Kousis, 1996); infrastructural development, hike in facilities which in turn help in improving the standard of life for inhabitants of destination region (Garland, 1984; Milman \& Pizam, 1988; Coccossis, 1996).
Social, cultural, technological, economic, political, and external environment are factors shaping the socio-cultural traits of local community. Analyzing tourism implications without the interference of above mentioned factors has not yet been addressed because these influences have not yet been controlled and detached from tourism development (Crick, 1996). Thus chief motive of studying these influences, that is the socio-cultural impact analysis intended to be conducted, is to make various stakeholders aware about the behavior and conduct of tourism growth in their concerned area in order to maximize positive attributes and reduce the negative ones. So this research deals only with impacts perceived by residents as the impacts of tourism development.

\subsection{Positive and Negative Socio-Cultural Impacts of Tourism}

Travis (2011) is of the opinion that socio-cultural implication associated with tourism are basically the combination of social as well as cultural influences of tourism over hosts arising due to the interactive nature of the guest-host relationship magnified by the influence of tourism industry. Zhuang, Yao and Li (2019:3) mentioned that socio-cultural implications arise because tourism activity involves human element which result in the degradation of hosts' quality of life in addition to cultural deterioration.

Tourists move from destination to destination but prefer to visit places in the vicinity of host communities. Tourists belong to different cultural backgrounds in contradictory to host community, therefore chances of socio - cultural influences are frequently possible. This view was aided by Saayman (2013) who believed socio- cultural influences occur at the destination spot via interactions of hosts and tourists.

Many researchers were of the view that interaction between tourist and host favours the inter change of stock, services and notions (De Kadt, 1979; Sharpley, 2014; Carneiro \& Eusébio, 2015). This interchange forms the foundation of interaction between tourist and host and will help in improving the relationship. Fletcher et al. (2013) was of the view that if the interchange or interaction is fabricated ultimately host tourist relationships comes under negative analysis of social interaction, contrary to this if host- tourist relationship is thought full, sensible and deep of course interaction will come under positive aspect then the relationship may be considered to be positive in nature. 
The seminal work of Mathieson and Wall (1982) illustrates socio cultural impacts of tourism under three elements, viz "Tourists", "Hosts" and "The encounter". Tourists affect linguistic, cultural and wealth patterns of local population. They have profound influence on socio cultural tourism.

Since majority of the people who deliver the tourism products and services are hosts so they are the first people who come across tourists by sharing their native place or by performing for the sector. The interaction occurring between guest and host results in the shift in the conduct of host community whose impacts are durable. However, the magnitude of this shift in behavior depends upon the circumstances under which this interaction occurs, position of the destination on TALC and the social carrying capacity of destination (Mathieson \& Wall, 1982; Tichaawa \& Mhlanga, 2015).

Cooper (2016) stated the momentum of the distress caused by tourists to the hosts as well as the reaction of hosts are predicted by three important facets: (a) Local communities' behavior as a reaction to tourism will be dictated by the degree to which tourist facilities located at destination will be accessible to locals. (b) the duration for which locals stay within their locality will determine their know-how regarding the attitude towards tourism. (c) the perception of locals towards tourism will also be predicted by the extent to which hosts or their kinsfolk will be employed within tourism related sectors because it will provide them the first hand exposure to the sector. In case the locals are benefited by the tourism they will develop a welcoming attitude towards it.

International tourism provides key opportunity for the interaction between two diverse cultures when a tourist from developed nation goes around a destination in emergent nation (Dogan, 1989). Since tourists are not aware about local culture and hence may be exploited by locals by providing tourists with simplified and condensed experiences of the area (Cohen, 1988; Wall \& Mathieson, 2006).

In this way the inborn hospitality of locals may be commodified. Due to the difference in the economic status between tourists and hosts, hosts feel subservient and their relation turns out to be impractical (Wall \& Mathieson, 2006). With regard to the perceived tourism impacts in their study Vareiro \& Mendes, 2015 residents' perspectives on tourism impacts of Portuguese World Heritage historic centers: Angra do Heroísmo and Évora found that residents from Angra do Heroísmo have a stronger agreement about the impacts of tourism on their city than the residents of Évora, except for the negative social and cultural impacts.

In a study conducted by Aduabuchi (2015) showed that tourism has different impacts based on differences in products, management strategies, activities created, location, occupation, ownership and closeness to the parkland, and level of households" involvement. Among the positive impacts indicated by Pandam household respondents are employment (95.56\%), fishing $(84.44 \%)$, preservation of culture $(68.89 \%)$, increase in population $(51.11 \%)$, supply of fish to the community market (48.89\%), proliferation of private enterprises $(42.22 \%)$ and biodiversity conservation (24.44\%).

In one more study carried out by Kamat, Scaglione, Pillai, amd Chen (2016) on the socio, economic, and environmental impacts of casino tourism in Goa found that age, gender, income, education, length of residence was found to have a significant impact on perceptions about casino tourism. And more recently in 2019 a study was carried out by Lizarraga regarding the impacts of residential tourism revealed that residential tourism in the region generates important negative social, cultural, political and environmental effects, such as social polarization, hoarding of natural resources, privatization of public spaces and degradation of the ecosystem.

\section{METHODOLOGY}

In an attempt to address the purpose of this study, a quantitative research approach was adopted. Using the systematic random sampling method data was collected from the host community of Gulmarg tourist destination during the months of April 2019 to July 2019. Respondents were approached in their homes and only one respondent was considered per household. This has made the sample more representative of the population of the host community.

The inclusion criteria specifically comprised of local residents that were between the ages of 18 and 60 years, both males and females; employed and unemployed local residents and residents involved (either directly or indirectly) in tourism activities at the destination.

\subsection{Instrument}

The questionnaire had two sections. The first section referred to the socio demographic 
characteristics of the respondents, namely age, gender, years of Residency, household income and involvement in tourism.

The second part of the questionnaire evaluated the perception of host community regarding to the social and cultural impacts of tourism. Host communities were asked to rate 18 statements on a 5point Likert scale from 1 to 5 where " 1 " meant "totally disagree" and " 5 " meant "totally agree". The questionnaire was based on the literature, but the final version was specially designed for this study.

\subsection{About Study Setting}

Situated at an altitude of $2730 \mathrm{~m}$ above sea level, Gulmarg is a popular skiing destination located in Pir Panjal Range of Union territory of Jammu and Kashmir. Surrounded by snow-covered lofty Himalayas, meadows of flowers, deep ravines, evergreen forested valleys, Gulmarg also has the world's second-highest Gondola ride.

The slopes in Gulmarg vary between 8,700 and 10,500 feet and are the highest skis in India. There is also a green 18-hole golf course in Gulmarg which is also the world's highest golf course. One can also hire the golf sets from Gulmarg. The Golf Club offers shortterm memberships to the players. Gulmarg also offers some excellent opportunities for long walks.

Walking along Gulmarg's circular path you only have to look down to have a complete view of the valley including Srinagar. A fine view can also be had of Nanga Parbat, the naked mountain which is over 26,000 feet and dominates the entire region. For a funfilled ride of a most unusual kind, Gulmarg's newly constructed gondola lift through pine-clad slopes is an experience of a lifetime.

This gondola will take you up above 15,000 feet and is one of the highest in the world. Here, a tourist can touch the skies and merge with the clouds. Gulmarg has also been a popular destination for shooting of various Bollywood films.

\subsection{Sampling Design}

The study was conducted in the Gulmarg tourist destination of Jammu and Kashmir, India. The sample for the study was the residents whose age was 18 years or above residing in the selected villages. The sample frame was obtained from the electoral rolls provided by the concerned Block Development Officer (BDO) of the area.
The method of collecting quantitative data from the respondent's sample of these identified and independent sampling units has been the systematic random sampling.

First, the sampling interval was obtained by using the formula (total number of household residents, obtained from electoral voter list/sample size obtained by using Taro Yamane). Then using the random number table, we selected a family number between 1 and the obtained sampling interval. These obtained families were then approached to collect data through direct door-to-door interviews.

\subsection{Sample Size}

The selection of an optimum sample size is the core concern of a researcher to come up with a reliable study. Using a formula for a 95\% confidence level (Yamane, 1973), we obtained the sample size for the present study as follows

$$
n=\frac{N}{1+N(e) 2}
$$

Where :

$\mathrm{n}=$ sample size required

$\mathrm{N}=$ number of people in the population

$\mathrm{e}=$ allowable error $(\%)$

As per the records provided by the Block Development Officer (BDO) of the area, the electoral roll of the destination in May 2018 was 260. So the sample size by using the Taro Yamane (1973) formula for the study was 157 . However, only 147 responses (93\%) were found to be appropriate for the analysis of the data.

\subsection{Data Analysis and Results}

\subsubsection{Results of Reliability}

Reliability analysis of socio-cultural impacts of tourism was tested through Cronbach Alpha Coefficient. The Cronbach's alpha for both the dimensions were above 0.7 which is considered as an acceptable cut-off value (Nunnally 1978; Hair, et al., 1998) meaning that all factors in this study were reliable.

As a result of the reliability analysis, the general reliability value of the data relevant to the scale about overall socio-cultural impacts of tourism (Cronbach Alpha Coefficient) was found to be 0.905. Thus the data generated through the questionnaires is reliable (Nunnally, 1978). The results of the reliability test are shown in table 1. 
Table 1: Results of Reliability Test

\begin{tabular}{|l|l|l|}
\hline Dimensions & No. of items & Chronbach Alpha $(\alpha)$ Value \\
\hline Socio-Cultural Positive Impacts & 07 & .898 \\
\hline Socio-Cultural Negative Impacts & 08 & .963 \\
\hline Overall Socio-Cultural Impacts & 15 & .904 \\
\hline Note: Chronbach Alpha $(\alpha)$ for all the constructs are above threshold level.60 \\
\hline
\end{tabular}

Source: own elaboration.

\subsubsection{Demographic Results}

As indicated in Table 2, 66\% ( $n=98$ ) of respondents were male while as $34 \%(n=49)$ were females. Approximately $46 \%$ ( $n=68$ ) of households are residing there for $20-30$ years. The majority of the participants were associated with the local business (59\%, $n=87)$, and only $16 \%$ ( $n=23)$ were involved in Govt. jobs. Most of the respondents were in the age of 18-32 years $(43 \%, n=63)$. The majority of the respondents were directly involved $(40 \%, n=59)$ in the tourism activities at the destination.

Table 2: Profile of respondents (Demographic)

\begin{tabular}{|c|c|c|c|c|}
\hline Age & $\begin{array}{l}18 \text { to } 32 \text { years } \\
(43 \%)\end{array}$ & $\begin{array}{l}32-46 \text { years } \\
(38 \%)\end{array}$ & $\begin{array}{l}46-60 \text { years } \\
(14 \%)\end{array}$ & $\begin{array}{c}60 \text { above } \\
(5 \%)\end{array}$ \\
\hline \multicolumn{2}{|l|}{ Gender } & $\begin{array}{l}\text { Male } \\
(66 \%)\end{array}$ & & $\begin{array}{l}\text { Female } \\
(34 \%)\end{array}$ \\
\hline Occupation & $\begin{array}{l}\text { Local Business } \\
(59 \%)\end{array}$ & $\begin{array}{l}\text { Govt. Job } \\
(16 \%)\end{array}$ & $\begin{array}{c}\text { Professionals } \\
\text { (19\%) }\end{array}$ & $\begin{array}{c}\text { Others } \\
(6 \%)\end{array}$ \\
\hline Years of Residency & $\begin{array}{l}1-10 \text { years } \\
(17 \%)\end{array}$ & $\begin{array}{c}10-20 \text { years } \\
(25 \%)\end{array}$ & $\begin{array}{c}20-30 \text { years } \\
(46 \%)\end{array}$ & $\begin{array}{l}\text { above } 30 \text { years } \\
(12 \%)\end{array}$ \\
\hline $\begin{array}{l}\text { Household income } \\
\text { (Annual) }\end{array}$ & $\begin{array}{l}\text { Less than Rs. 50,000 } \\
(36 \%)\end{array}$ & \multicolumn{2}{|c|}{$\begin{array}{l}\text { Rs.50, 000-Rs. 1, 00,000 } \\
(38 \%)\end{array}$} & $\begin{array}{l}\text { e Rs. 1, } \\
(26 \%)\end{array}$ \\
\hline $\begin{array}{l}\text { Involvement in } \\
\text { tourism }\end{array}$ & $\begin{array}{l}\text { directly employed } \\
(40 \%)\end{array}$ & $\begin{array}{l}\text { indirectly employed } \\
(32 \%)\end{array}$ & $\begin{array}{l}\text { not employed } \\
(23 \%)\end{array}$ & $\begin{array}{l}\text { Employed in the } \\
\text { tourism industry other } \\
\text { than my village (5\%) }\end{array}$ \\
\hline
\end{tabular}

\section{Source: own elaboration.}

\subsubsection{Results of Factor Analysis}

Factor analysis was applied to determine the factors of impacts of tourism. The principal components analysis and Varimax rotation (vertical rotation) techniques were used to determine the factor structure and to obtain significant interpretable factors. The data with eigenvalue higher than 1 and the data with factor load higher than 0.50 were taken into consideration. The 15 items got reduced to 02 factors as a result of the factor analysis; factors were classified based on their original names i.e. Socio-Cultural Positive Impacts and Socio-Cultural Negative Impacts.

The values of Kaiser-Meyer-Olkin (KMO) value were .894and Barttlett test of Sphericity (Chi-Square = 1980.224; df: 105; sig. = 000) indicate the data adequacy for factor analysis. The extracted factors accounted $71.762 \%$ of variance. The results of factor analysis are shown in table 3

Table 3: Factor Analysis Results

\begin{tabular}{|c|c|c|c|c|}
\hline Attributes & $\begin{array}{l}\text { Factor } \\
\text { loading }\end{array}$ & Mean & $\begin{array}{l}\text { Standard } \\
\text { Deviation }\end{array}$ & $V E$ \\
\hline \multicolumn{5}{|l|}{ Socio-Cultural Negative Impacts (SCNI) } \\
\hline Tourism has increased crime in the area (SCN4) & .926 & 2.93 & 1.664 & \\
\hline Tourism has increased prostitution and sex permissiveness in the area (SCN3) & .921 & 2.65 & 1.835 & \\
\hline Tourism denies local people access to tourist destination (SCN5) & .919 & 2.97 & 1.726 & \\
\hline $\begin{array}{l}\text { Tourism developments have forced local people to be relocated from their } \\
\text { traditional settlements (SCN1) }\end{array}$ & .910 & 2.64 & 1.880 & 43.36 \\
\hline $\begin{array}{l}\text { Tourism leads to increases in the local prices of some goods and services including } \\
\text { land (SCN7) }\end{array}$ & .907 & 2.78 & 1.758 & \\
\hline $\begin{array}{l}\text { Tourism has stimulated migration of people to the area in search for jobs and } \\
\text { related tourism opportunities (SCN6) }\end{array}$ & .900 & 2.76 & 1.749 & \\
\hline $\begin{array}{l}\text { Tourism has changed the way of life of people by following the western culture in } \\
\text { their dress, behaviour, food (SCN2) }\end{array}$ & .866 & 2.89 & 1.584 & \\
\hline Tourism has led to loss of objectivity of local traditions (SCN8) & .786 & 2.97 & 1.759 & \\
\hline
\end{tabular}




\begin{tabular}{|c|c|c|c|c|}
\hline OVERALLMEAN & & 2.82 & 1.55 & \\
\hline \multicolumn{5}{|l|}{ Socio-Cultural Positive Impacts (SCPI) } \\
\hline Tourism provides jobs for local residents (SCPI2) & .832 & 4.36 & .721 & \\
\hline Tourism activities have improved personal income of the local people (SCPI5) & .824 & 4.18 & .808 & \\
\hline $\begin{array}{l}\text { Tourism is good because the money spent by tourists stimulates the local economy } \\
\text { and is good for the local businesses (SCPI6) }\end{array}$ & .821 & 4.35 & .808 & \\
\hline Tourism promotes development and better maintenance of public facilities (SCPI3) & .788 & 4.24 & .734 & 28.39 \\
\hline Tourism has improved security in the area (SCPI4) & .771 & 4.20 & .730 & \\
\hline Tourism has rejuvenated the local culture (SCPI7) & .768 & 4.10 & .825 & \\
\hline Tourism is conserving your cultural heritage which could have died (SCPI1) & .705 & 4.11 & .778 & \\
\hline OVERALLMEAN & & 4.21 & .608 & \\
\hline
\end{tabular}

Source: own elaboration.

In summary, Factor 1 "Socio-Cultural Negative Impacts" comprised 08 items that explained $43.36 \%$ of the variance. The eigenvalue was 6.505 and the overall mean was 2.82. For Factor 2 "Socio-Cultural Positive Impacts", there were 07 items explaining $28.39 \%$ of the variance, the eigenvalue being 4.259 with the overall mean of 4.21 .

As shown in Table 3 mean value of Socio-Cultural Negative Impacts is less than five point scale (where 1 $=$ strongly disagree and $5=$ strongly agree). Thus the values depict that host communities do not tourists perceive high negative socio-cultural impacts of tourism. The study also revealed host communities perceive high positive socio-cultural impacts of tourism as the overall mean value for it is 4.21 . This indicates that host communities strongly agree with the positive socio-cultural impacts of tourism.

\subsubsection{Confirmatory Factor Analysis (CFA)}

Confirmatory Factor Analysis (CFA) was executed in order to endorse the constructs and to confirm the measurement properties. In addition to the usual Chisquare values, the other goodness of fit indices like such as CFI, IFI, GFI, AGFI and RMSEA were used in order to examine the goodness of fit. Initially model fit indices were examined to check the goodness of fit. The initial model fit indices were $X^{2}=254.825, d f=89$; Probability level $=.000 ; C M I N / D F=2.863 ; C F I=0.915$; $|F|=0.916 ; T L I=0.900 ;$ and $R M S E A=0.113$. This model fit was not so good. Thus to achieve well model fit the error terms e10-e15 and e4-e6 were co-varied. This increased the model fit and the results of model fit indices were $X^{2}=185.396, d f=87$; Probability level $=$ .000; CMIN/DF = 2.131; CFI = $0.950 ; I F I=0.950 ; T L I=$ 0.939; and RMSEA $=0.088$. The results of the CFA indicate that the data fits the model very well.

From the Table 4 it is evident that the Composite Reliability (CR) values for all the measured constructs of the developed model were above than the recommended threshold of 0.60 (Koufteros, 1999). Furthermore, the values of the Average Variance Extracted (AVE) in all the cases were above than the threshold of 0.50 (Fornell \& Larcker, 1981). Thus the values obtained from $C R$ and AVE favour the reliability and convergent validity of the measured constructs.

Table 4: Results of Confirmatory Factor Analysis

\begin{tabular}{|c|c|c|c|c|}
\hline Dimensions & Loadings & Sig. & AVE & $C R$ \\
\hline \multicolumn{5}{|l|}{ Socio-Cultural Negative Impacts (SCNI) } \\
\hline $\begin{array}{l}\text { Tourism has changed the way of life of people by following the western culture in their dress, } \\
\text { behaviour, food (SCNI7) }\end{array}$ & .911 & *** & & \\
\hline $\begin{array}{l}\text { Tourism has stimulated migration of people to the area in search for jobs and related tourism } \\
\text { opportunities (SCNI6) }\end{array}$ & .873 & $* * *$ & & \\
\hline Tourism leads to increases in the local prices of some goods and services including land (SCNI5) & .922 & $* * *$ & 0.767 & 0.963 \\
\hline $\begin{array}{l}\text { Tourism developments have forced local people to be relocated from their traditional settlements } \\
\text { (SCNI4) }\end{array}$ & .900 & $* * *$ & & \\
\hline Tourism denies local people access to tourist destination (SCNI3) & .914 & $* * *$ & & \\
\hline Tourism has increased prostitution and sex permissiveness in the area (SCNI2) & .824 & $* * *$ & & \\
\hline Tourism has increased crime in the area (SCNI1) & .902 & $* * *$ & & \\
\hline Tourism has led to loss of objectivity of local traditions (SCNI8) & .743 & $* * *$ & & \\
\hline \multicolumn{5}{|l|}{ Socio-Cultural Positive Impacts (SCPI) } \\
\hline Tourism has rejuvenated the local culture (SCPI6) & .828 & $* * *$ & & \\
\hline Tourism has improved security in the area (SCPI5) & .717 & $* * *$ & & \\
\hline
\end{tabular}




\begin{tabular}{|c|c|c|c|c|c|c|c|c|c|c|}
\hline \multicolumn{7}{|c|}{ Tourism promotes development and better maintenance of public facilities (SCPI4) } & .763 & $* * *$ & 0.545 & 0.892 \\
\hline \multicolumn{7}{|c|}{$\begin{array}{l}\text { Tourism is good because the money spent by tourists stimulates the local economy and is good } \\
\text { for the local businesses (SCPI3) }\end{array}$} & .731 & $* * *$ & & \\
\hline \multicolumn{7}{|c|}{ Tourism activities have improved personal income of the local people (SCPI2) } & .848 & $* * *$ & & \\
\hline \multicolumn{7}{|c|}{ Tourism provides jobs for local residents (SCPI1) } & .616 & $* * *$ & & \\
\hline \multicolumn{7}{|c|}{ Tourism is conserving your cultural heritage which could have died (SCPI7) } & .635 & $* * *$ & & \\
\hline \multicolumn{11}{|c|}{ Goodness of fit índices } \\
\hline $\mathrm{x} 2$ & df & CMIN/DF & $\mathrm{CFI}$ & $\mathrm{IFI}$ & TLI & RMSEA & & & & \\
\hline 185.396 & 87 & 2.131 & 0.950 & 0.950 & 0.939 & 0.088 & & & & \\
\hline
\end{tabular}

\section{DISCUSSION}

Respondents were asked to comment on a set of 15 statements related to socio-cultural impacts of tourism to know the perception of host community in the tourist destination of Gulmarg. The findings of the study revealed that respondents agreed with all seven statements related to positive socio-cultural impacts of tourism.

The host community agreed ( $n=72$ i.e. $49 \%$ agreed and $n=67$ i.e. $45 \%$ strongly agreed) with the statements that Tourism provides jobs for local residents (SCPI2) with the mean score of 4.36; Tourism is good because the money spent by tourists stimulates the local economy and is good for the local businesses (SCPI6) ( $n=59$ i.e. $40.1 \%$ agreed and $n=73$ i.e. $49.7 \%$ strongly agreed) (mean=4.35); Tourism promotes development and bettermaintenance of publicfacilities (SCPI3) ( $n=77$ i.e. $52.4 \%$ agreed and $n=55$ i.e. $37.4 \%$ strongly agreed) (mean=4.24); Tourism has improved security in the area (SCPI4) ( $n=72$ i.e. $49 \%$ agreed and $\mathrm{n}=54$ i.e. $36.7 \%$ strongly agreed) (mean $=4.20$ ); Tourism activities have improved personal income of the local people (SCPI5) ( $n=77$ i.e. $52.4 \%$ agreed and $n=52$ i.e. $35.4 \%$ strongly agreed) (mean=4.18); Tourism is conserving your cultural heritage which could have died (SCPI1) ( $n=74$ i.e. $50.3 \%$ agreed and $n=47$ i.e. $32 . \%$ strongly agreed) (mean=4.11); and Tourism has rejuvenated the local culture (SCPI7) ( $n=76$ i.e. 51.7\% agreed and $n=47$ i.e. $32 . \%$ strongly agreed) (mean=4.10). These results confirm to the findings highlighted by Inskeep (1991) and Cooper et al (2008).

The tourism industry's ability to create job opportunities for local people and tourist spending in the destination that boosts the local economy and local business in the tourist destination of Gulmarg emerged as one of the most important positive socio-cultural impacts of tourism development. The local people value the employment opportunities which have been created by the tourism industry. Host community also value that tourism promotes development and better maintenance of public facilities and improved security in the area.

The fact that the respondents are agreed with that tourism results in improved infrastructure and has been built in the area over the last 10 to 20 years. This has made the tourist destination more accessible to the hosts and visitors.

The increasing number of tourists visiting the area has also resulted in high demand for local cultural products such as souvenirs and handicraft products as host community value tourism as a conserving and preserving agent for cultural heritage and local culture as well. This supports findings by Gursoy and Rutherford (2004), Dyer et al. (2007), and Ryan et al. (2011) who indicate that tourism development brings in more business opportunities for local people.

The findings of the study also revealed that security in the area has also increased because of the tourism activities at the tourist destination. This confirms Lankford and Howard (1994) and Ap and Crompton's (1998) findings that the presence of tourists and tourism development in an area improves security as local authorities find it necessary to provide a secure environment for tourism businesses and tourists.

The second part of the survey encompassed eight statements on the negative socio-cultural impacts of tourism development. The local residents did not agree with any of the negative socio-cultural impacts of tourism. Host community of the destination disagreed with tourism has increased crime, prostitution and other illegal activities in the area.

The local residents also disagreed that tourism stimulates migration of people to a tourist area in search of jobs and other tourism related opportunities. The respondents also disagreed that tourism 
development has led to a loss of objectivity of local traditions.

The host communities perceive that this destination has significant tourism development, the local culture and traditions of the area have not been affected in anyway. It was noted that the local people in the area have a strong belief in following their traditions. That is why tourism activities in the area have not resulted in the commoditization and demonstration effect.

The results of this research contradict Lankford and Howard (1994) and Mbaiwa (2005) who indicate that tourism can increase crime in a tourist area as the respondents disagreed with this negative impact of tourism.

Since Kashmir is considered safest place for tourist as per the records of National Crime Record Bureau report that no case of crime against foreigners emerged in J\&K during 2016, 2017 and 2018. As the place is safest so accordingly the residents perceive that tourism activities do not generate negative impacts. As per the reports there was no case of violence, sexual assault, rape, forgery, theft and cheating reported from Jammu and Kashmir against the foreigners who visited the region in these years.

The respondents also disagreed that tourism developments force people to be relocated from their traditional settlements. The host community of the destination does not perceive negative socio-cultural impacts of the tourism because the tourism activities at the destination are not being operated at large scale and is seasonal in nature.

Also tourism impacts are likely to change over time as a destination area develops (Butler, 1980). So in future the host communities may perceive negative impacts of tourism but presently they are of the opinion that tourism phenomenon at the destination is not producing the negative impacts.

These findings of our study are also in line with the results of Aduabuchi, 2015 who found that no negative impact was indicated from Assop falls management by household respondents. Besides, Empirical research tends to suggest that local residents in many locations are willing to consider trade-offs in relation to tourism - they are willing to accept some negative consequences as long as tourism is perceived as bringing some benefits. This is particularly so where tourism is one of a small range of choices.

\section{CONCLUSION AND SUGGESTIONS}

\subsection{Summarinzing}

This investigation has examined local host community's perceptions towards socio-cultural impacts of tourism in Gulmarg, a tourist destination in Kashmir. The literature review identified several impacts of tourism as a result of tourism development and the tourist-host interrelationships.

A quantitative methodology through questionnaire drafted on the previous literature was adopted to determine the perceived socio-cultural impacts of tourism on the local communities. The host residents perceive that the tourism development is creating employment opportunities, improving local peoples' incomes, and stimulating the local economy. Residents in tourist destination also agreed that tourism has improved security in their local communities and has preserved and conserved the local culture and traditions of the area.

Furthermore, the findings of the survey revealed that host communities do not perceive any sociocultural negative impact of the tourism development in the area. As noted by Jurowski and Gursoy's (2004) research on residents' perceptions towards tourism and its effects will continue to be of interest as the sustainability of tourism development is highly dependent on local people's goodwill.

Therefore, the findings highlighted in this paper can assist tourism planners and local authorities in the planning and implementation of tourism development strategies for the area aiming at consolidating local residents' support for tourism. It is appropriate to know residents' perceptions on tourism impacts in order to incorporate community reaction into tourism planning and development. Therefore, future research could focus on examining the factors that affect local residents' participation in tourism.

The Government tourism planners should introduce tourism awareness programmes for local residents to let them know about the concepts, benefits and problems of local tourism development. Furthermore, the Government should start involving the local communities of Gulmarg area in the tourism planning process to ensure that the development is sensitive to its social and cultural impacts.

It should be noted that given the opportunity local communities can organize and represent themselves effectively such that their contributions in the planning process could be vital (Brohman, 1996). 
The Government through the Department of Tourism and Gulmarg Development Authority (GDA) should have control of tourism developments in the area to ensure that only appropriate tourism facilities and establishments are constructed and opened in the area. Thus, tourism establishments should adopt sound practices like Incorporation of local architectural styles, educating local communities, planned landscaped areas, code of conduct for guests for interaction, etc. Such activities have been suggested by the researchers advocating the responsible tourism and have already been implemented by the destinations of South Africa favouring the Responsible Tourism Practices.

This would inevitably contribute to the quality of surroundings, improving the experience for guests and the living standards of local communities. The private sector operating in the tourism sector should also be encouraged to support the home stay concept so that host communities can earn maximum from the tourism activities in the area.

Further to this, the private sector and Government should collaborate to support the local communities by constructing some infrastructure (e.g. stalls or shops) for the local communities where they can be selling their arts and crafts to tourists. This would improve local people's access to tourists when they want to sell their products to them.

\subsection{Limitations and directions for future studies}

The study has certain limitations that should be considered for future research, for example, it was carried out using a quantitative methodology, based on cross-sectional data, and adopted demographic variables like gender and social status that should be considered as moderating variables. Thus, future studies could focus on (a) longitudinal studies, (b) to consider other impacts of tourism along with other variables like community support, quality of life of host communities, etc., (c) use a qualitative methodology in order to gain more insights into the phenomenon, and (d) involve mediating variables like community participation in the relationship of socio-cultural impacts of tourism and community support.

\section{REFERENCIAS}

Acha-Anyi, P.N. (2016). Planning and development of sustainable tourism products in local communities. African Journal of Hospitality, Tourism and Leisure, 5 (3), $1-20$.
Aduabuchi ljeomah, H. M. (2015). Impact of tourism on livelihood of communities adjoining ecodestinations in Plateau State, Nigeria. CULTUR-Revista de Cultura e Turismo, 6(3), 55-71.

Allcock, J .B. (1986) Yugoslavia's Tourist Trade: Pot of Gold or Pig in a Poke?' Annals of Tourism Research 13,4:565-88.

Alrwajfah, M. M., Almeida-García, F. \& Cortés-Macías, R. (2019). Residents' perceptions and satisfaction toward tourism development: a case study of Petra Region, Jordan. Sustainability, 11(1907), 1-19.

Ap, J. (1992). Residents' perceptions on tourism impacts. Annals of Tourism Research, 19 (4), 665-690.

Ap, J., \& Crompton, J. L. (1998). Developing and testing a tourism impact scale. Journal ofTravel Research, 37 (2), 120-130.

Binns, T., \& Nel, E. (2002). Tourism as a local development strategy in South Africa. The Geographical Journal, 168 (3), 235-247.

Brougham, J.E. and Butler, R.W. (1977) The Social and Cultural Impact of Tourism: A Case Study of Sleat, Isle of Skye, Edinburgh: Scottish Tourist Board.

Brunt, P., \& Courtney, P. (1999). Host perceptions of sociocultural impacts. Annals of Tourism Research, 26 (3), 493-515.

Butler, R. W. (1980). The concept of a tourist area cycle of evolution: implications for management of resources.Canadian Geographer/Le Géographe canadien, 24(1), 5-12.

Cohen, E. (1984) 'The Sociology of Tourism: Approaches, Issues and Findings', Annual Review of Sociology, 10: 373-92. London: Routledge, pp. 15-50.

Cohen, E. (1988). Authenticity and commoditization in tourism. Annals of Tourism Research, 15 (3), 371-386.

Cooper, C. \& Hall, C. M. (2008). Contemporary tourism: an International approach. London: Elsevier.

Cooper, C., Fletcher, J., Fyall, A., Gilbert, D., \& Wanhill, S. (2008). Tourism: Principles and practice. Harlow: Financial Times Prentice Hall.

Crandall, L. (1987) 'The Social Impact of Tourism on Developing Regions and Its Measurement' in B. J. R. Ritchie and C. R. Goeldner (eds) Travel, Tourism and Hospitality Research, New York: John Wiley \& Sons, pp. 413-23.

Crick, M. (1989). Representations of international tourism in the social sciences: Sun, sex, sights, savings, and servility. Annual review of Anthropology, 18, 307-344.

Dann, G., and E. Cohen. (1991). Sociology and Tourism. Annals of Tourism Research 18(1): 155-169

Davison, R. (1996). The impacts of tourism. Tourism Destinations, 18-45.

De Kadt, E. (1979). Tourism: Passport to development? Perspectives on the social and cultural effects of tourism in developing countries. Oxford: Oxford University Press.

Deery, M., Jago, L. \& Fredline, L. (2012). Rethinking social impacts of tourism research: a new research agenda. Tourism Management, 33(5), 64-73. 
Doğan, H. Z. (1989). Forms of adjustment: Sociocultural impacts of tourism. Annals of Tourism Research, 16(2), 216-236.

Duffield, B. S. and Long, J. (1981) 'Tourism in the Highlands and Islands of Scotland: Rewards and Conflict', Annals of Tourism Research, 8, 3: 403-31.

Dyer, P., Gursoy, D., Sharma, B., \& Carter, J. (2007). Structural modeling of resident perceptions of tourism and associated development on the Sunshine Coast, Australia. Tourism Management, 28 (2), 409-422.

Eshliki, S. A. \& Kaboudi, M. (2012). Community perception of tourism impacts and their perception in tourism planning: a case study of Ramsar, Iran. Procedia: Social and Behavioral Sciences, 36, 333-341.

Fletcher, J., Fyall, A., Gilbert, D. \& Wanhill, S. (2013). Tourism: principles and practice (5thed.). United Kingdom: Pearson Education Limited.

Fornell, C., and D. F. Larcker (1981). Evaluating Structural Equation Models with Unobservable Variables and Measurement Error. Journal of Marketing Research, 18(1):39-50.

Fox, M. (1977) 'The Social Impact of Tourism: a Challenge to Researchers and Planners' in B. R.Finney and A.Watson (eds) A New Kind of Sugar: Tourism in the Pacific, Santa Cruz: Center for South Pacific Studies, University of California, pp. 27-48.

Garland, B. R. (1984) New Zealand Hosts and Guests. A Study on the Social Impact of Tourism, Palmerston North: Market Research Centre, Massey University.

George, R. (2015). Managing tourism in South Africa (2nd ed.). Cape Town: Oxford University Press Southern Africa.

Graburn, N. H. H. (1983) 'Tourism and Prostitution', Annals of Tourism Research, 10, 3: 437-43.

Hair, J. F., Anderson, R. E., Tatham, R. L., \& Black, W. C. (1998). Factorial analysis. Multivariate Data Analysis. Fifth edition. New Jersey: Prentice Hall.

Haukeland, J. V. (1984) 'Sociocultural Impacts of Tourism in Scandinavia', Tourism Management, 5, 3: 207-14.

Inskeep, E. (1994). National and Regional Tourism Planning: Methodologies and Case Studies. London: Routledge.

Jafari, J. (1989) 'Sociocultural Dimensions of Tourism. An English Language Literature Review' in J. Bystrzanowski (ed.) Tourism as a Factor of Change, Vienna: The Vienna Centre, pp. 17-60.

Jeffs, S. and Travis, A. (1989) 'Social, Cultural and Linguistic Impact of Tourism in and upon Wales' in J. Bystrzanowski (ed.) Tourism as a Factor of Change. National Case Studies, Vienna: The Vienna Centre, pp. 90-114.

Kamat, K., Scaglione, M., Pillai, S. K. B., \& Chen, R. F. (2016). The socio, economic, and environmental impacts of casino tourism in Goa. Revista Latino-Americana de Turismologia, 2(1), 44-54.

Koufteros, X. A. (1999). Testing a model of pull production: a paradigm for manufacturing research using structural equation modeling. Journal of operations Management, $\quad$ 17(4), 467-488.
Kousis, M. (1996) 'Tourism and the Family in a Rural Cretan Community' in Y. Apostopoulos et al. (eds) The Sociology of Tourism, London: Routledge, pp. 219-32. Krippendorf, J. (1987) The Holiday Makers. Understanding the Impact of Leisure and Travel, Oxford: Heinemann.

Lankford, S. V. (1994). Attitudes and perceptions toward tourism and rural regional development. Journal of Travel Research, 32 (3), 35-43.

Lizarraga, O. (2019). Impacts of US Residential Tourism in Northwest Mexican Coastal Destinations: the cases of Mazatlán, Sinaloa; Cabo San Lucas, Baja California Sur and Puerto Peñasco, Sonora. Revista Latino-Americana De Turismologia, 5(1 e 2). https://doi.org/10.34019/2448-198X.2019.v5.25892

Manivannan, B. (2015). Social impact of tourism in India. International Journal of Innovative Research in Technology, Science \& Engineering, 1(4), 118-124.

Mathieson, A., \& Wall, G. (1982). Tourism, economic, physical and social impacts. London: Longman.

Mason, P. (1990) Tourism. Environment and Development Perspectives, Godalming: World Wide Fund for Nature.

McKercher, B. (1993). Some fundamental truths about tourism: understanding tourism's social, and environmental impacts. Journal of Sustainable Tourism, 1,6-16.

Milman, A. and Pizam, A. (1988) Social Impacts of Tourism on Central Florida, Annals of Tourism Research, 15, 2:191204.

Mill, R.C. (1990) Tourism: The International Business, Englewood Cliffs, NJ: Prentice Hall.

Netemeyer, R. G., Bearden, W. O., \& Sharma, S. (2003). Scaling procedures: Issues and applications. Sage Publications.

Nettekoven, L. (1979) 'Mechanisms of Intercultural Interaction' in E. de Kadt Tourism-Passport to Development? Perspectives on the Social and Cultural Effects of Tourism in Developing Countries, New York: Oxford University Press, pp. 135-45.

Nunnally, J. C. (1978). Psychometric Theory McGraw-Hill Book Company. INC New York.

O'Grady, R. (ed.) (1990) The Challenge of Tourism, Bangkok: Ecumenical Coalition on Third World Tourism.

Oppermann, M., \& Chon, K. S. (1997). Tourism in developing countries. London: International Thomson Business Press.

Pearce, D. G. (1989) Tourist Development, 2nd edn, Harlow: Longman.

Peck, J. G. and Lepie, A. S. (1989) 'Tourism and Development in Three North Carolina Coastal Towns' in V. L. Smith (ed.) Hosts and Guests: the Anthropology of Tourism, Philadelphia: University of Pennsylvania Press, 2nd edn, pp. 203-22.

Pizam, A. and Milman, A. (1984) 'The Social Impacts of Tourism', UNEP Industry and Environment, 7, 1: 11-14.

Reisinger, Y., and L.W. Turner. (2003). Cross-Cultural Behaviour in Tourism: Concepts and Analysis. Oxford: Butterworth- Heinemann. 
Ryan, C., Chaozhi, Z., \& Zeng, D. (2011). The impacts of tourism at a UNESCO heritage site in China-a need for a meta-narrative? The case of the Kaiping Diaolou. Journal of Sustainable Tourism, 19 (6), 747-765.

Sharpley, R. (2014). Host perceptions of tourism: a review of the research. Tourism Management, 42, 37-49.

Smith, V. (1977). Hosts and guests: The anthropology of tourism (1st ed.). Philadelphia: University of Pennyslvania Press.

Smith, V.L., and Brent. (2001). Hosts and guests Revisited: Tourism issues of the $21^{\text {st }}$ Century. New York: Cognizant Communication Corporation.

Sutton, W. A. (1967). Travel and Understanding: Notes on the Social Structure of Touring. International Journal of Comparative Sociology, 8, 2: 218-23.

Tichaawa, T. M. \& Mhlanga, O. (2015). Community perceptions of a community-based tourism project: a case study of the CAMPFIRE programme in Zimbabwe. African Journal for Physical Health Education, Recreation and Dance (AJPHERD), 1 (Suplement):5567.

Tosun, C. (2002). Host perceptions of impacts: A comparative tourism study. Annals of Tourism Research, 29 (1), 231253.

Tovar, C., \& Lockwood, M. (2008). Social impacts of tourism: An Australian regional case study. International Journal of Tourism Research, 10 (4), 365-378.

Tsartas, P. (1992) 'Socioeconomic Impacts of Tourism on Two Greek Islands', Annals of Tourism Research) 19, 3: 51633.
UNESCO (1976) 'The Effects of Tourism on Socio-Cultural Values', Annals of Tourism Research, 4, 2: 74-105.

Vareiro, L. C., \& Mendes, R. (2015). Residents' perspectives on tourism impacts of Portuguese World Heritage historic centers: Angra do Heroísmo and Évora. Tourism \& Management Studies, 11(1), 44-51.

Vaughan, R. and Long, J. (1982) 'Tourism as a Generator of Employment: A Preliminary Appraisal of the Position in Great Britain', Journal of Travel Research, 21, 2: 27-31.

Verbole, A. (1995) 'Pros and Cons of Rural Tourism Development: A Discussion on Tourism Impacts and Sustainability, with a Case from Slovenia', Paper presented at the XVIth Congress of the European Society for Rural Sociology, Prague.

Wallace, J.M.T. (1997) Putting Culture into Sustainable Tourism: Negotiating Tourism at Lake Balaton, Hungary, Department of Sociology and Anthropology, North Carolina State University.

Wall, G. (1996). Rethinking impacts of tourism. Progress in Tourism and Hospitality Research, 2(3-4), 207-215.

Wall, G., \& Mathieson, A. (2006). Tourism: Change, impacts, and opportunities. Harlow: Pearson Education.

White, P. E. (1974) The Social Impact of Tourism on Host Communities: A Study of Language Change in Switzerland, Oxford: School of Geography, University of Oxford.

WTTC. (2020). Travel \& Tourism Economic Impact 2020 World https://wttc.org/Research/Economic-Impact

Young, G. (1973) Tourism: Blessing or Blight, Harmondsworth: Penguin.

\footnotetext{
Processo Editorial / Editorial Process / Proceso Editorial

Editor Chefe / Editor-in-chief / Editor Jefe: PhD Thiago D. Pimentel (UFJF).

Recebido / Received / Recibido: 28.11.2020; Revisado / Revised / Revisado: 03.12.2020-01.02.2021; Aprovado / Approved /

Aprobado: 10.03. 2021; Publicado / Published / Publicado (online): 16.03.2021.

Tradução do original do autor / Translation of author's original paper / Texto traducido de la versión original del autor. Seção revisada às cegas por pares / Double blind review section / Sessión revisada por pares ciegos.
} 